\title{
The Effect of Evotherm on Hot Mix Asphalt
}

\author{
Andrew Abah Onoja, Hashim Mohammed Alhassan \\ Bayero University, Kano, Nigeria \\ Email: elandyin@gmail.com
}

How to cite this paper: Onoja, A.A. and Alhassan, H.M. (2019) The Effect of Evotherm on Hot Mix Asphalt. Engineering, 11, 557-575.

https://doi.org/10.4236/eng.2019.119039

Received: July 30, 2019

Accepted: September 7, 2019

Published: September 10, 2019

Copyright $\odot 2019$ by author(s) and Scientific Research Publishing Inc. This work is licensed under the Creative Commons Attribution International License (CC BY 4.0).

http://creativecommons.org/licenses/by/4.0/

\begin{abstract}
There has been a paradigm shift globally from high combustion rates of all human activities that contribute to global warming. Environmental awareness has been increasing rapidly over the past years. In these regards, Evotherm, which is a Fatty-Amine derivative of the hydrocarbon chain, was investigated and used in the production of asphalt to examine the effect. The overall influence of the admixture and temperature was examined. Seven (7) Laboratory specimens with different additive contents of $0 \%, 0.25 \%, 0.5 \%, 0.75 \%$, $1.0 \%, 1.25 \%$ and $1.5 \%$ were produced and compacted at different compaction temperatures of $100^{\circ} \mathrm{C}, 115^{\circ} \mathrm{C}, 130^{\circ} \mathrm{C}, 145^{\circ} \mathrm{C}$ and $160^{\circ} \mathrm{C}$, to evaluate Marshall Stability parameters. The binder content for the control test and admix samples were all kept constant for the range of 5.0\%, 5.5\%, 6.0\%, 6.5\% and 7\% by weight of total mix for all the trial mixes for proper and uniform observation and also for the determination of the optimal mix for the control and admix samples. For each specimen mix, two (2) Marshall cylindrical samples were compacted at heavy compaction level of 75 blows, which represent heavy traffic category, and the mean result obtained for accuracy. This was done for all the temperature categories. Therefore, for this research work, 350 cylindrical cubes of Marshall Samples were evaluated in the laboratory. The result shows that despite the modification on the asphalt by the Evotherm product, the admixed asphalt exhibited similar engineering properties as Hot Mix Asphalt even at lower temperature of $115^{\circ} \mathrm{C}$, and could be used as a first step in the promotion of improved carbon print from Nigerian Asphalt pavements.
\end{abstract}

\section{Keywords}

Global-Warming, Evotherm, Optimal Mix, Voids, Marshall Tests, Temperature and Pollution

\section{Introduction}

Environmental awareness has been increasing rapidly over the past years. Extensive measures like air pollution reduction targets set by the European Union 
with the Kyoto protocol have encouraged efforts to reduce pollution [1].

Persistent warnings regarding the adverse effects of the excessive emission of greenhouse gases most notably, carbon dioxide led to intensive efforts on a global scale to address these concerns culminating with the ratification of the Kyoto protocol by the European Union in which they pledged to lower the carbon dioxide emissions by $15 \%$ by 2010 and further reductions in future efforts [1].

These newly imposed environmental restrictions spurred the asphalt industry bodies in European countries to look into new approaches and techniques that lower emissions and energy consumption. The production of Hot Mix Asphalt (HMA) raises a number of environmental concerns because of the emission of gases such as $\mathrm{CO}_{2}, \mathrm{SO}_{2}$ and $\mathrm{NOx}$ into the atmosphere and the health risks encountered by both asphalt workers on the field and in the asphalt plants. The United Nations conference on the environment and sustainable development that was held in Rio de Janeiro in 1992 marked the beginning of universal awareness of the risks of damage facing this planet. The destruction of natural resources and climate change are the main causes of damage and disruption of ecosystems. Industry, agriculture, and transport are blamed for being the main contributors. This awareness was formalized in 1997 by the Kyoto Protocol to the United Nations Framework Convention on Climate Change, which featured in particular, a commitment made by signatory states to bring greenhouse gas emission rates down. Many research efforts have been carried out in response to the commitment in different areas, with all of such efforts tending to new modifications of existing technology to suit the environment. The asphalt industry, which also accounts in the massive contribution to the pollution, is not left out [1] [2].

An amendment to the United Nations Framework Convention on Climate Change was negotiated in Kyoto in 1997 and came into effect on February 16, 2005. The participating nations were expected to have reached noticeable success in 2005. Countries that ratify this protocol commit to reducing their collective emissions of six greenhouse gases by $5.2 \%$ compared to the year 1990, calculated as an average over the five-year period of 2008-2013. Conditions in each country were considered when national targets were set and they range from $8 \%$ reductions for the European Union to $10 \%$ permitted increases for countries such as Iceland with extremely cold temperature [2].

The asphalt paving industry is constantly exploring technological improvements that will enhance the materials' performance, increase construction efficiency, conserve resources, and advance environmental stewardship. Current and impending regulations on emissions and energy conservation are making attractive the new modifications in asphalt mix production [3].

With the prices of crude oil increasing and reserves of natural non-renewable resources dwindling over time, the needs for adopting greener and more sustainable approaches in various construction activities are stronger. The asphalt production industry has been keen during the last few decades to reduce the impact of its activities on the environment especially regions adjacent to its op- 
erating activities and on natural resources [3].

Researchers have been trying to reduce the mixing/compaction temperature of HMA since the 1970s by utilizing the moisture in the aggregate, foaming the binder, and of course, using emulsified asphalts [4].

Reducing the HMA production temperature and the placement temperature could bring several economical, environmental, and even performance benefits. Certain members of the asphalt industry are studying technology for reducing production temperatures by $50^{\circ} \mathrm{F}$ or more within the next decade. One category of current promising products has been termed Warm-Mix Asphalt (WMA). Although WMA is in its infancy, the technology and its potential benefits are stirring significant interest in Europe North America, and other countries interested in economical, environmentally friendly paving materials [5].

Producing asphalt at lower temperatures know as Warm Mix Asphalt (WMA) is a technology that allows significant lowering of the production and paving temperature of conventional Hot Mix Asphalt (HMA). By reducing the viscosity of bitumen and/or increasing the workability of the mixture, some WMA technologies can reduce the temperature significantly without compromising the performance of the asphalt. This promises various benefits over HMA, e.g. lowering the greenhouse gas emissions, lowering energy consumption, improved working conditions and better work ability and compaction [6].

The evolution of Warm Mix technologies of asphalt production in Europe was driven by a number of identified benefits acquired through the adoption of these technologies. The most notable benefits reported are the reduction in harmful emissions and energy consumption. Moreover, improvements in compaction enable the extension of the pavement season and longer haul distances. Lowering the heat used to produce asphalt mixes is not completely new in other parts of the world. The idea of saving energy and lowering emissions in the asphalt industry has been discussed for decades. In 1956, the potential of foamed bitumen for use as a soil binder was realized. Since then, foamed asphalt technology, which allows lower mixing temperatures, has been used successfully in different countries, including USA, Australia and Europe [7]. The original process consisted of injecting steam into hot bitumen.

In 1968, Mobil Oil Australia, which had acquired the patent rights for Csanyi's invention, modified the original process by adding cold water rather than steam into the hot bitumen [8]. The bitumen foaming process then became more practical.

In the early 1970s, Chevron developed new methods to prepare paving mixtures stabilized by emulsified asphalt. In 1977, Chevron published their "Bitumuls Mix Manual" [8].

The United States Clean Air Act was passed into law in 1970. The first Earth Day was held that same year. Since that time, US industries have worked to become better environmental stewards [9].

Technologies that allow lower HMA production temperatures may demonstrate positive impacts on pavement performance, because the technologies im- 
prove the workability of the mix, they should reduce (or, at least, certainly not increase) compaction energy requirements and, thus, enhance in-place density [10].

Enhanced compaction is, of course, a key parameter regarding performance. Furthermore, the majority of aging of asphalt binder in HMA occurs in the plant when exposed to elevated temperatures. Lower mixing temperature will reduce oxidative hardening, which should reduce susceptibility to cracking by improving pavement flexibility and longevity [11].

With the development of the global economy, how to address sharply increasing demand for fossil fuels and reduce gas emissions has become a critical issue for society [12]. The asphalt industry is also always looking for an efficient way to reduce emissions and save energy.

The National Asphalt Pavement Association (NAPA) sent out a study team to Europe to evaluate and research three of the adopted European technologies in the summer of 2002. The NAPA study team visited asphalt production facilities, paving sites and completed road sections in Germany and Norway to study the use of synthetic zeolite, WMA and synthetic paraffin wax additive technologies [13]. Although the warm mix technologies were regarded as promising, certain questions persisted over its applicability to the United States in terms of climatic conditions, mix designs and construction practices. The need to initiate a research program to assist in answering these concerns was cited along with the necessity to implement demonstration projects that help in validating the performance of these technologies. Moreover, NAPA invited a selected group of European experts to introduce the European experience with WMA to the American HMA industry at the 2003 NAPA annual meeting in San Diego [14].

\subsection{Hot Mix Asphalt}

Hot-Mixed Asphalt (HMA), is commonly and massively used in Nigeria due to the fact that most roads are flexible pavement design. It is typically produced in either batch or drum mix asphalt plants at a discharge temperature ranging from $150^{\circ} \mathrm{C}$ to $163^{\circ} \mathrm{C}$. It has been necessary to use these elevated temperatures to dry the aggregates, coat them with the asphalt binder, achieve the desired workability, and provide sufficient time to compact the HMA mat [15] [16]. Traditional HMA is usually produced at temperatures between $140^{\circ} \mathrm{C}$ and $163^{\circ} \mathrm{C}(284$ and $\left.325^{\circ} \mathrm{F}\right)$ and compacted at about $80^{\circ} \mathrm{C}$ to $135^{\circ} \mathrm{C}\left(175\right.$ to $\left.275^{\circ} \mathrm{F}\right)$. The temperature of the asphalt mix has a direct effect on the viscosity of the asphalt cement binder and thus compaction. As hot mix asphalt temperature decreases, its asphalt cement binder becomes more viscous and resistant to deformation, which results in a smaller reduction in air voids for a given compactive effort. Eventually, the asphalt binder becomes stiff enough to prevent any further reduction in air voids regardless of the applied compactive effort. The temperature, at which this occurs, the cessation temperature, is considered to be about $79^{\circ} \mathrm{C}\left(175^{\circ} \mathrm{F}\right)$ for dense graded HMA mixes [17]. 
Hot Mix Asphalt (HMA) consists of a combination of aggregate uniformly mixed and coated with asphalt cement. To dry the aggregates and obtain sufficient fluidity of asphalt cement for proper mixing and workability, both the aggregate and bitumen must be heated prior to mixing hence the term "Hot Mix" [18].

HMA consists of two basic ingredients: aggregate and asphalt binder. HMA mix design is the process of determining what aggregate to use, what asphalt binder to use and what the optimum combination of these two ingredients ought to be. HMA mix should be designed to achieve the following properties: resistance to deformation, fatigue resistance, resistance to low temperature cracking, durability, resistance to moisture susceptibility, skid resistance and workability. There are basically three methods used to achieve the aforementioned, which are the Hveem, Marshall and Superpave methods [19]. All the methods are commonly used in other countries. Whereas, in Nigeria, Marshall method only is used to achieved the design and performance [17].

The specification that guides asphalt design in Nigeria using the Marshall Stability method is the Nigerian General Specification for Roads and Bridges [17]. The general guide to the design mix is shown in Table 1 for aggregate envelop and bitumen ranges for both Wearing and Binder courses.

For the analysis of the design, Table 2 states the basic engineering parameters to be considered in order to have a good design for good performance under traffic loading with corresponding upper and lower limits of specification band.

Table 1. Aggregate gradation/bitumen content limits for binder and wearing courses for HMA.

\begin{tabular}{cccc}
\hline \multicolumn{2}{c}{ BS Sieve Sizes } & Binder course & Wearing course \\
Inches & mm & $(\%)$ & 100 \\
\hline $1 "$ & 25.00 & $90-100$ & 100 \\
$3 / 4$ & 19.00 & $70-90$ & $85-100$ \\
$1 / 2$ & 12.50 & $55-80$ & $75-92$ \\
$3 / 8$ & 9.50 & $47-70$ & $65-82$ \\
$1 / 4$ & 6.30 & $40-60$ & $50-65$ \\
No. 8 & 2.36 & $27-45$ & $36-51$ \\
No. 16 & 1.18 & $20-34$ & $26-40$ \\
No. 30 & 0.60 & $14-27$ & $18-30$ \\
No. 50 & 0.30 & $8-20$ & $13-24$ \\
No. 100 & 0.15 & $5-15$ & $7-14$ \\
No. 200 & 0.75 & $2-6$ & $5.0-8.0$ \\
\hline
\end{tabular}

Source: Nigerian General Specification for Roads and Bridges (1997). 
Table 2. Properties/specification of compacted hot mix asphalt.

\begin{tabular}{cccc}
\hline S/No. & Properties & Binder course & Wearing course \\
\hline 1. & Optimum Bitumen Content & $4.5 \%-6.5 \%$ & $5.0 \%-8.0 \%$ \\
2. & Stability & Not less than $3.5 \mathrm{kN}$ & Not less than $3.5 \mathrm{kN}$ \\
3. & Flow & $2 \mathrm{~mm}-6 \mathrm{~mm}$ & $2 \mathrm{~mm}-4 \mathrm{~mm}$ \\
4. & Void in Total Mix & $3 \%-8 \%$ & $3 \%-5 \%$ \\
5. & Void Filled with Bitumen & $65 \%-72 \%$ & $75 \%-82 \%$ \\
\hline
\end{tabular}

Source: Nigerian General Specification for Roads and Bridges (1997).

\subsection{Evotherm}

Evotherm is a new generation chemical additive developed in the USA by MeadWestvaco Asphalt Innovations, Charleston, South Carolina (now Ingevity Inc.). It is based on a chemical process that can be delivered in the form of high residue asphalt emulsion. Water in the form of steam is released when the Evotherm is mixed with hot aggregate. Evotherm can also be delivered as a water based soap solution known as Evotherm DAT, or as a chemical package that does not contain water known as Evotherm-3G. The chemistry that led to the successful production of the Evotherm has the potential to improve coating, workability, and adhesion in asphalts [20].

The Evotherm technology can also be modified and delivered in three different forms as described below.

1) Evotherm ET (Emulsion Technology) (First Generation)—a high asphalt cement (AC) content, water-based asphalt emulsion. Evotherm ET requires no plant modifications.

2) Evotherm DAT (Dispersed Asphalt Technology) (Second Generation)—a concentrated solution of Evotherm additives in-line injected at the mix plant. Evotherm DAT allows for flexibility.

3) Evotherm 3G (Third Generation) - This was developed in partnership with Paragon Technical Services and Mathy Technology \& Engineering. This category of Evotherm, which is an Evotherm, 3G is in water-free form [21].

\section{Materials and Experiments}

The experimental design of this research work was grouped into three distinct stages which include; preliminary investigation, laboratory investigation and detailed investigation of all materials used for the research work including the control asphalt mix samples and all the admixed samples. Table 3 shows the basic properties of the bitumen used, which met all the required specification for a good asphalt mix.

The laboratory work carried out on the aggregates samples, gave the results in Table 4, which all are within specification, therefore accepted for the research work.

Table 5 shows most of the Evotherm-3G properties with fatty-amine properties and high flash point with no loss on ignition. The properties are categorized 
Table 3. Laboratory test on bitumen.

\begin{tabular}{cccc}
\hline S/No. & Test & Results (average) & Remarks \\
\hline 1. & Penetration at $25^{\circ} \mathrm{C}$ & 64 & OK \\
2. & Fire and Flash Points & $250^{\circ} \mathrm{C}$ & OK \\
3. & Specific Gravity & 1.02 & OK \\
\hline
\end{tabular}

Table 4. Laboratory test on aggregates.

\begin{tabular}{cccc}
\hline S/No. & Test & Average Result & $\begin{array}{c}\text { FMW \& H } \\
\text { Specification }\end{array}$ \\
\hline 1. & Aggregate Crushing Value (ACV) & $28 \%$ & $<35 \%$ \\
2. & Aggregate Impact Value (AIV) & $30 \%$ & $<35 \%$ \\
3. & Elongation Index & $26 \%$ & $<30$ \\
4. & Flakiness Index & $28 \%$ & $<30$ \\
5. & Water Absorption & $0.5 \%$ & $\mathrm{NA}$ \\
6. & Specific Gravity $(10-14 \mathrm{~mm})$ & 2.69 & $\mathrm{NA}$ \\
\hline
\end{tabular}

Table 5. Physical and chemical properties of Evotherm-3G.

\begin{tabular}{ccc}
\hline S/No. & Description & Properties \\
\hline 1. & Product Identifier & EVOTHERM-3G \\
2. & Chemical Name & Fatty-amine derivative \\
3. & Physical State & Liquid \\
4. & Colour & Amber (Dark) \\
5. & Odour & Amine-like \\
6. & $\mathrm{P}^{\mathrm{H}}$ Value & 10 to $12(\mathrm{Conc} .(\% \mathrm{w} / \mathrm{w}): 15 \%)$ \\
7. & Melting Point & $<-30^{\circ} \mathrm{C}\left(<-22^{\circ} \mathrm{F}\right)$ \\
8. & Boiling Point & $>200^{\circ} \mathrm{C}\left(>392^{\circ} \mathrm{F}\right)$ \\
9. & Flash point & Closed cup: $>266^{\circ} \mathrm{C}\left(>510^{\circ} \mathrm{F}\right)$ \\
10. & Vapour Pressure & $<1.0 \times 10^{-10} \mathrm{mmHg} @ 25^{\circ} \mathrm{C}$ \\
11. & Relative Density & $0.97(\mathrm{Water}=1)$ \\
12. & Solubility & Partially soluble in Hot and Cold water \\
13. & Partition Coefficient: & n-octanol $/$ water: 2.2 \\
14. & Auto-ignition Temperature & $365^{\circ} \mathrm{C}$ to $375^{\circ} \mathrm{C}\left(689^{\circ} \mathrm{F}\right.$ to $\left.707^{\circ} \mathrm{F}\right)$ \\
15. & Flammability & $\mathrm{NA}$ \\
\hline
\end{tabular}

Source: Ingevity Corporation, Carolina USA, 2015.

into physical and chemical state as shown. Flammability was represented by flash point which is above $266^{\circ} \mathrm{C}$.

\section{Asphalt Mix Design}

An asphalt concrete is a high-quality, carefully controlled hot mixture of asphalt cement and well-graded, high-quality aggregate thoroughly compacted into a 
uniform dense mass.

The first step in obtaining this "high-quality mixture" is known as the mix-design. A successful mix design of recommended mixture of aggregate and asphalt binder is Asphalt Mix Design.

For HMA manufacturing, target values of gradation and asphalt binder content are specified based on the mix design along with allowable specification bands to allow for inherent material and production variability.

The end-result of a successful mix design is a recommended mixture of aggregate and asphalt binder as shown in Table 6. This recommended mixture, which also includes aggregate gradation and asphalt binder type is often referred to as the Asphalt Mix Design.

From the analysis, the asphalt mix design obtained for research work through the Marshall investigation is as shown in Table 6. It represents a complete batch of mix by weight for any size of production.

\section{Results and Discussion}

Seven (7) Laboratory specimens with different additive contents ( $0 \%, 0.25 \%$, $0.5 \%, 0.75 \%, 1.0 \%, 1.25 \%$ and $1.5 \%)$ were compacted at different Five (5) compaction temperatures $\left(100^{\circ} \mathrm{C}, 115^{\circ} \mathrm{C}, 130^{\circ} \mathrm{C}, 145^{\circ} \mathrm{C}\right.$ and $\left.160^{\circ} \mathrm{C}\right)$ as shown in Figure 1 in order to evaluate Marshall Stability parameters. The binder content for the control test and admix samples were kept constant for the range of $5.0 \%$, $5.5 \%, 6.0 \%, 6.5 \%$ and $7 \%$ for all the trial mixes for proper and uniform observation and also for the determination of the optimal mix for the control and admix samples. For each specimen mix, two (2) Marshall cylindrical samples were compacted at heavy compaction level ( 75 blows) and the mean result obtained for accuracy.

The combination of the mixes gave a total of 175 samples, which was doubled for the purpose of obtaining average. This further makes the actual total of samples to be 350 cylindrical Marshall samples.

The laboratory analysis and results are presented in tables and graphics that follows, for easy interpretations and use.

The presentation in Figure 2 shows all the various results obtained for the mix at different production temperatures. At $100^{\circ} \mathrm{C}$, the material was poorly coated

Table 6. Summary of asphalt mix design.

\begin{tabular}{cccc}
\hline S/No. & Materials & $\begin{array}{c}\text { Screen Sizes } \\
(\mathrm{MM})\end{array}$ & $\begin{array}{c}\text { Designed Proportions } \\
(\%)\end{array}$ \\
\hline 1. & $1 / 2$ inch size of aggregates & 12.5 & 19.0 \\
2. & $3 / 8$ size of aggregates & $5-10$ & 21.0 \\
3. & Stone Dust & $0-5$ & 48.0 \\
4. & Filler & $0-1$ & 6.0 \\
5. & NA & & 6.0 \\
& Tot70 Pen Bitumen & & $100 \%$
\end{tabular}




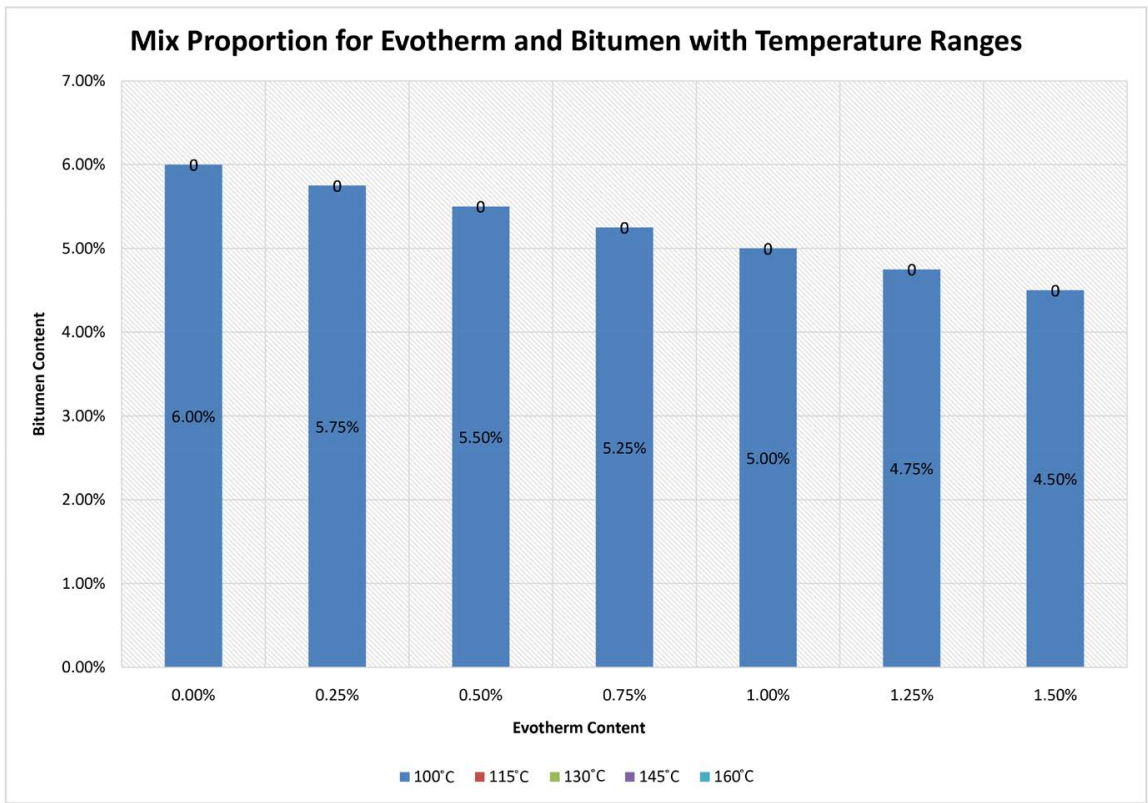

Figure 1. Mix proportion for Evotherm/bitumen and production temperatures.

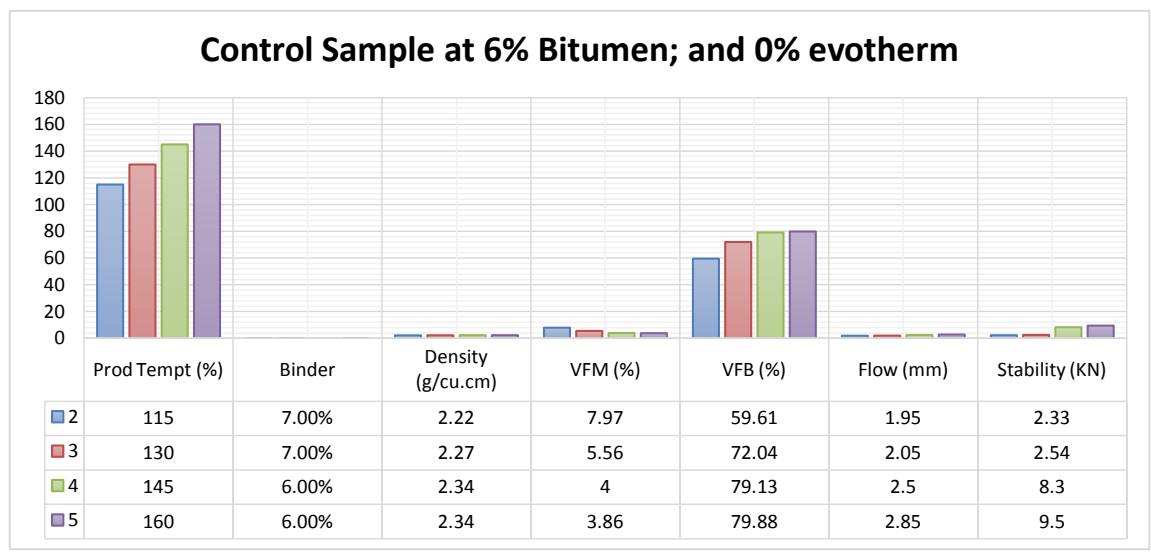

Figure 2. Summary of results for control sample used at optimal bitumen content.

due to low temperature, which is normal for HMA production at low temperatures, as such, compaction was not enough to produce any result as the compacted sample dissolved in the water bath during the soaking process at $60^{\circ} \mathrm{C}$.

For quality assurance purpose, an extraction test was carried out as one of the reverse engineering method of checking the conformity of already-mixed asphalt to the targeted design mix as represented in Figure 3.

The extraction test enables a check on compliance with the supposed bitumen content designed for mix and also checks the aggregate gradations whether it is in conformity with required aggregate envelope for the mix design.

Figure 4 shows a stage of production at which the mix is till performing like the conventional HMA with enhanced compaction densities which shows initial reaction of Evotherm. It exhibits similar behavior like the control mix, except for an initial compaction at $100^{\circ} \mathrm{C}$ which was not successful for the control mix. 


\begin{tabular}{|l|c|c|c|c|c|c|c|c|c|c|}
\hline Sieves(mm) & $\mathbf{1 9 . 0}$ & $\mathbf{1 2 . 5}$ & $\mathbf{1 0 . 0}$ & $\mathbf{6 . 3}$ & $\mathbf{2 . 3 6}$ & $\mathbf{1 . 1 8}$ & $\mathbf{0 . 6}$ & $\mathbf{0 . 3}$ & $\mathbf{0 . 1 5}$ & $\mathbf{0 . 0 7 5}$ \\
\hline Upper Limits(\%) & 100 & 100 & 92 & 82 & 65 & 51 & 40 & 30 & 24 & 14 \\
\hline Total passing(\%) & 100 & 90.4 & 81.7 & 70.5 & 59.2 & 48.2 & 38.0 & 26.4 & 16.7 & 7.7 \\
\hline Lower Limits(\%) & 100 & 85 & 75 & 65 & 50 & 36 & 26 & 18 & 13 & 7 \\
\hline
\end{tabular}

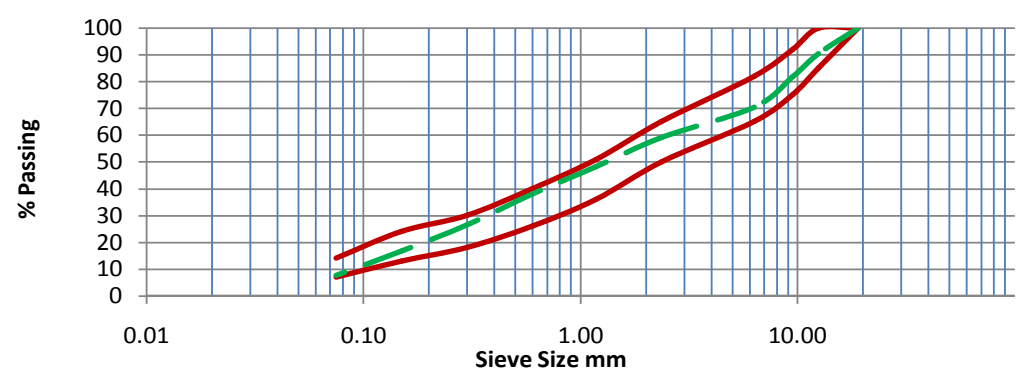

Figure 3. Result of extraction test for the HMA optimal mix.

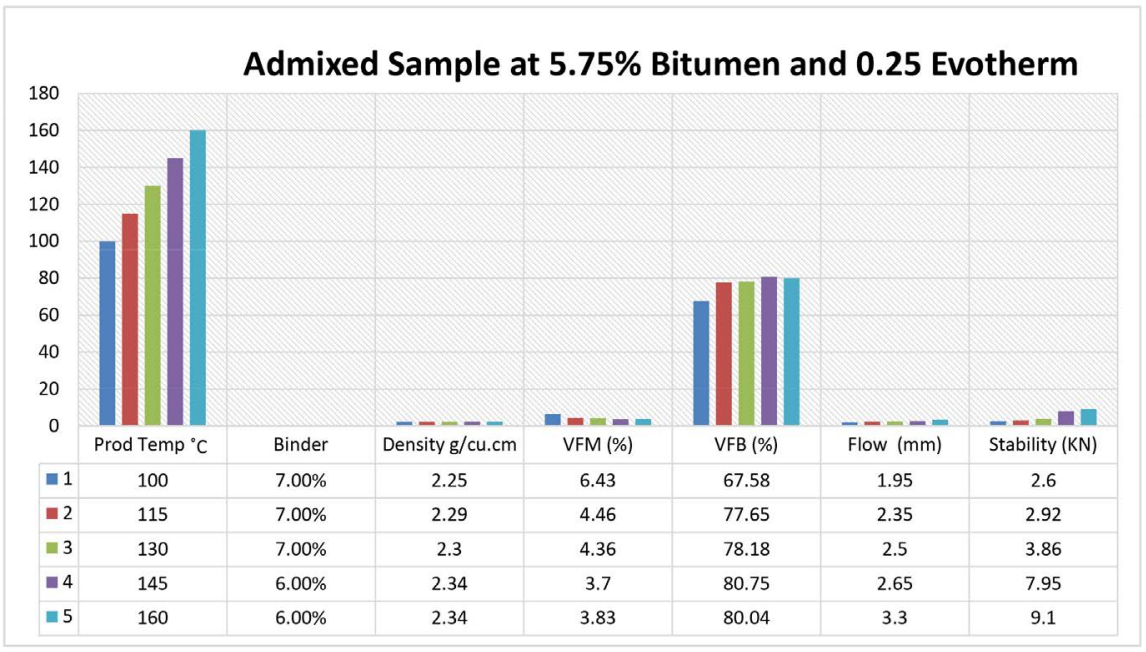

Figure 4. Summary of results for admix sample at $0.25 \%$ Evotherm content and $5.75 \%$ bitumen content.

At $0.50 \%$ Evotherm content and $5.50 \%$ bitumen content, the mix shows a better bonding property with more compaction densities as compared with the former at $0.25 \%$ Evotherm mix. Figure 5 showed a stage of mix where the material still behaves like the conventional HMA with all parameters exhibiting the properties of HMA, but with an enhanced compaction and coating at early temperature of $100^{\circ} \mathrm{C}$. For $0.25 \%$ and $0.50 \%$ of Evotherm content, the mix was able to withstand the 1-hour soaked period in the water bath, which when compared with the Control sample, it was in the contrary as the sample at $100^{\circ} \mathrm{C}$ production temperature failed by dissolution in the water bath after 30 minutes of soaking. This is an indication of Evotherm enhancing compaction rates.

There is better performance at $0.75 \%$ Evotherm content and $5.25 \%$ bitumen content as shown in Figure 6. At production temperatures of $100^{\circ} \mathrm{C}$ to $160^{\circ} \mathrm{C}$, the mix is very stable even though at lower stability at $100^{\circ} \mathrm{C}$, but above the minimum requirement of $3.5 \mathrm{KN}$ according to specification. It shows better consistency in compaction that controls the voids in the sample. It has an indication of good performance at lower production temperature as can be evidenced with 


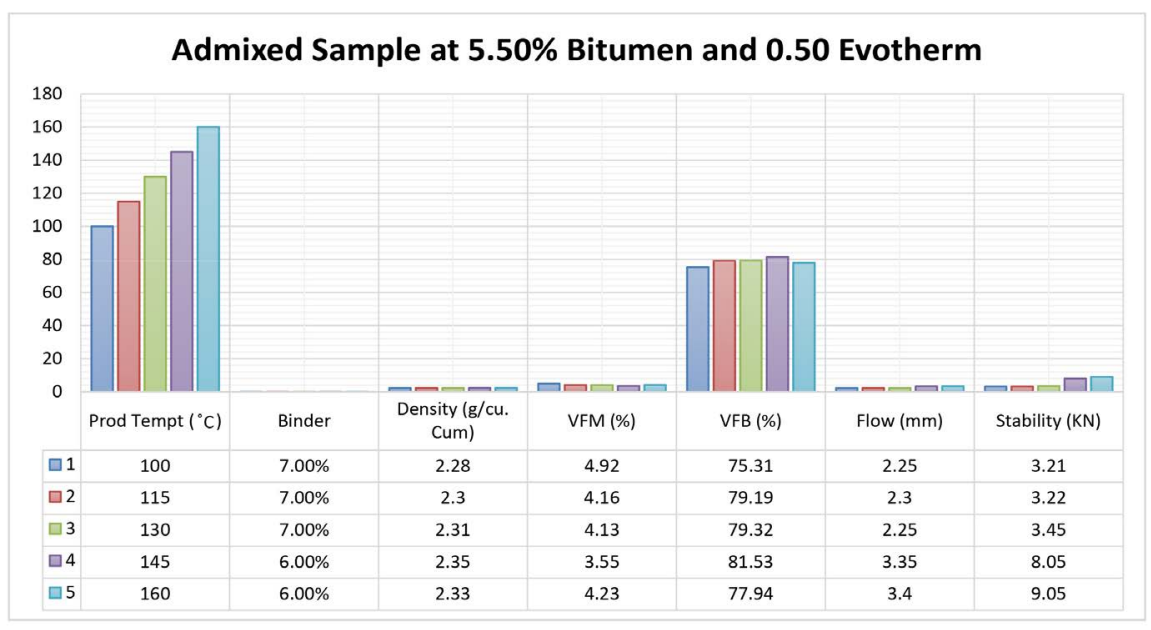

Figure 5. Summary of result for admix sample at $0.50 \%$ Evotherm content and $5.50 \%$ bitumen content.

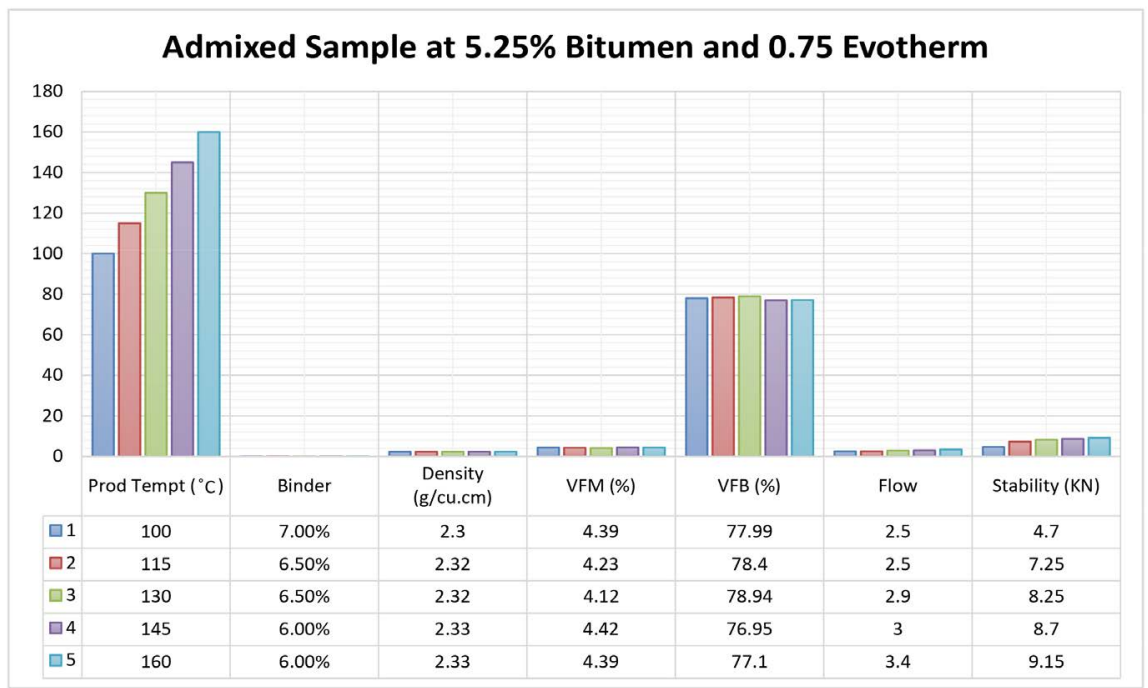

Figure 6. Summary of result for admix sample at $0.75 \%$ Evotherm content and $5.25 \%$ bitumen content.

the results at $100^{\circ} \mathrm{C}$ to $115^{\circ} \mathrm{C}$ in Figure 6 satisfying most of the design parameters.

Figure 7 shows the result with optimal performance. The mix is at $1 \%$ Evotherm content by weight of binder and $5 \%$ Bitumen content by weight of binder. The bitumen content of $5 \%$ is the least acceptable for a wearing course design as specified by Nigerian Standard. This shows that the bitumen content that gave the optimal mix is within the specification. It gives asphalt produced and compacted at lower temperature when mixed with $1 \%$ Evotherm by weight of binder content than the conventional production temperature with all the parameter satisfying HMA design parameters. The Optimal Mix as indicated in Figure 7 is at $115^{\circ} \mathrm{C}$ production temperature, $1 \%$ Evotherm by weight of binder, $5 \%$ Bitumen content by weight of binder mix ratio and $6 \%$ binder content by weight of total mix designed. 


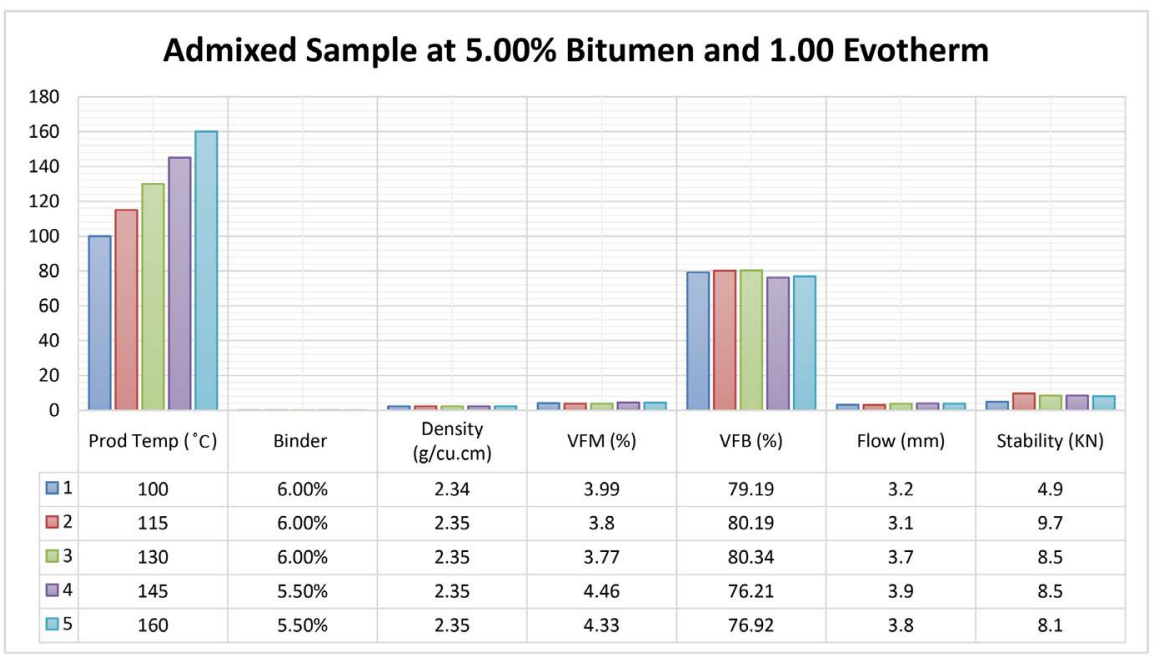

Figure 7. Summary of result for admix sample at $1.00 \%$ Evotherm content and $5.00 \%$ bitumen content.

More so, for quality assurance purpose of the optimal mix for the admixed samples indicated in Figure 7 at a production temperature of $115^{\circ} \mathrm{C}$, an extraction test was carried out as one of the reverse engineering method of checking the conformity of already-mixed asphalt produced at lower temperature to the targeted design mix.

At higher content of Evotherm with the mix ratio of 1.25\% Evotherm content by weight of binder and $4.75 \%$ bitumen content by weight of binder, the material shows a little decline in the performance as evidenced in Figure 8. The flow which is a function of deformation is high, which could be responsible for the drop in stability. The high flow of the sample is not unconnected with the increased content of Evotherm, giving the mix a high workability property thereby, the increase in flow and decrease in stability. There is a sharp drop in stability when compared to production with $1 \%$ Evotherm content by weight of binder and $5 \%$ bitumen content by weight of binder.

Finally, Figure 9 represents results at 1.50\% Evotherm content and $4.50 \%$ bitumen content. As evidenced from the table, there is a further decline in stability and flow even at low temperature, which indicates the reactiveness of Evotherm at higher quantity. The higher the quantity of Evotherm, the lower the quantity of bitumen, which increases the rate of reaction by increasing the workability of the asphalt produced. This property also guided the research limit of Evotherm percentage range in the investigation.

\section{Discussion of Engineering Parameters}

The basic engineering parameters in Marshall method of asphalt investigation are the bulk density, Voids in Total Mix, Voids Filled with Bitumen, Marshall Flow and Marshall Stability. The behaviors of these parameters aforementioned affect the judgement of selection of the best performing asphalt mix. The graphical presentations in Figure 10 to Figure 14 represent the various behaviors of 


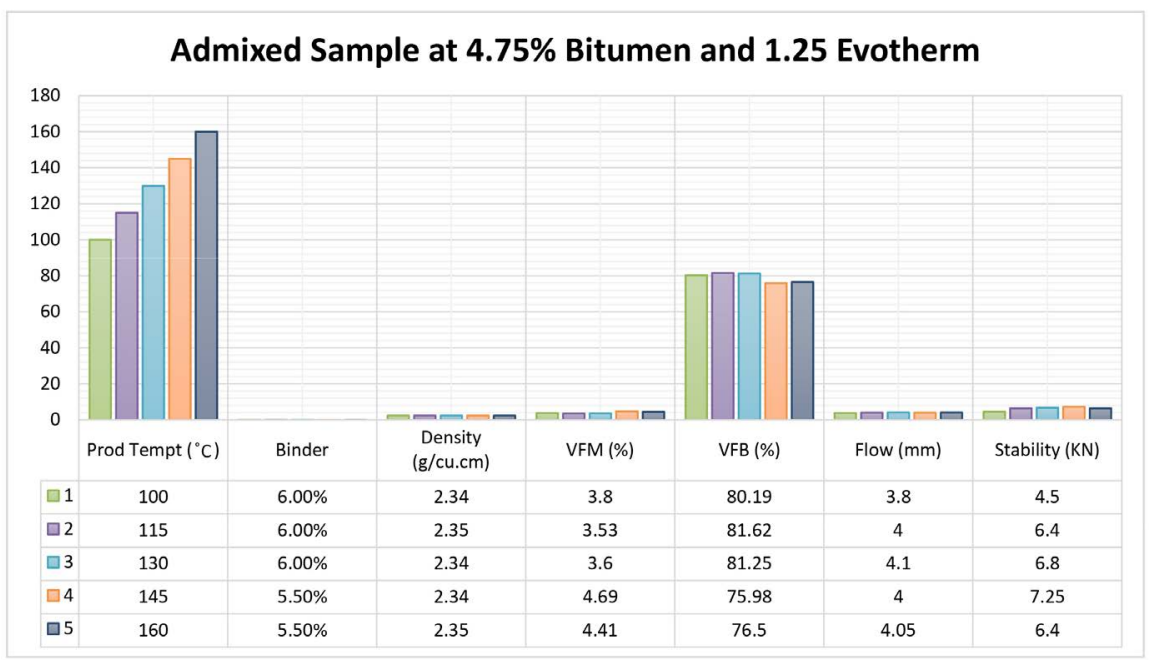

Figure 8. Summary of result for admix sample at $1.25 \%$ Evotherm content and $4.75 \%$ bitumen content.

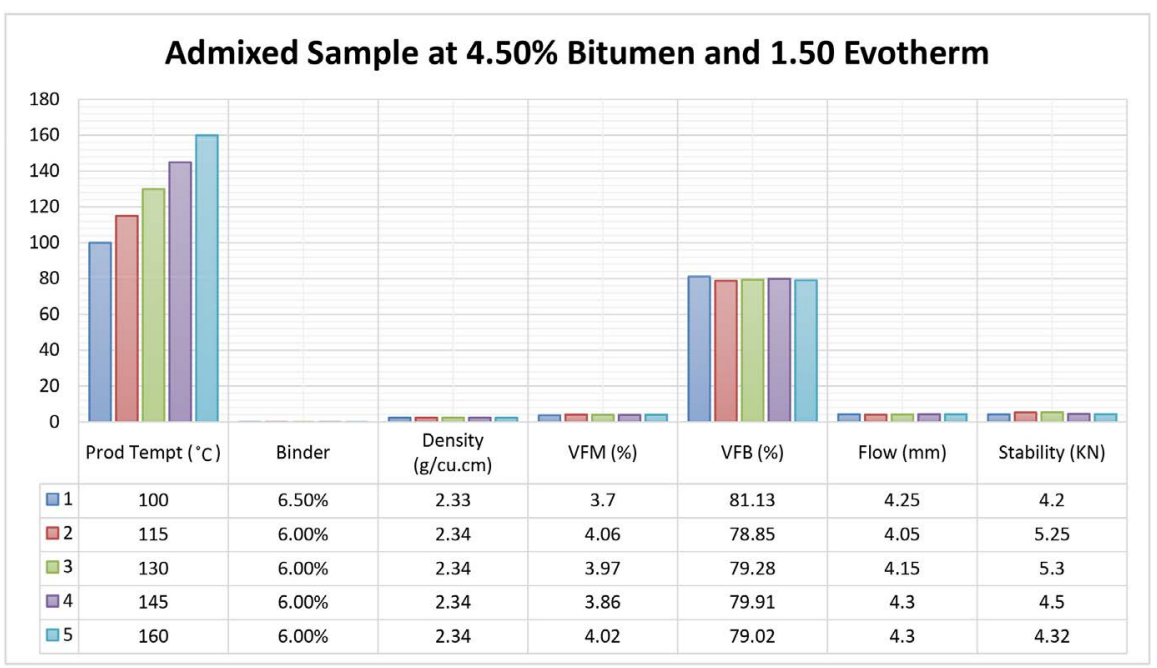

Figure 9. Summary of result for admix sample at $1.50 \%$ Evotherm content and $4.50 \%$ bitumen content.

these parameters under the different mix proportions and mix ratios and also at different production temperatures of $100^{\circ} \mathrm{C}$ to $160^{\circ} \mathrm{C}$.

Figure 10 shows that at a production temperature of $100^{\circ} \mathrm{C}$ for the control mix sample, the bulk density was undetermined due to lack of bonding of the sample at that temperature, at production temperature of $100^{\circ} \mathrm{C}$. The densities showed an increase pattern from $2.22 \mathrm{~g} / \mathrm{cm}^{3}$ at $100^{\circ} \mathrm{C}$ to $2.34 \mathrm{~g} / \mathrm{cm}^{3}$ at $160^{\circ} \mathrm{C}$. The density property for $145^{\circ} \mathrm{C}$ and $160^{\circ} \mathrm{C}$ showed similar behavior. This is a normal condition for HMA production as the temperatures were within the normal production temperatures for conventional HMA.

For the admixed sample, compaction was achieved at $100^{\circ} \mathrm{C}$. This is an indication that reaction exists between the bitumen and Evotherm. For $0.25 \%$ to $1.50 \%$ of Evotherm content by weight of binder and a corresponding decreasing 


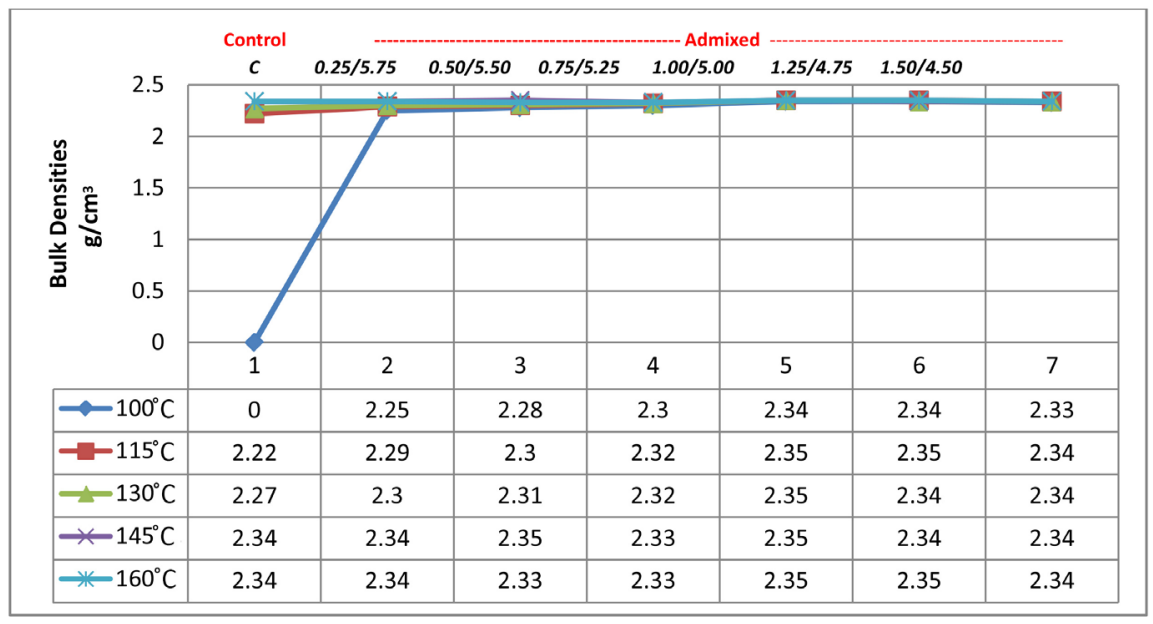

Figure 10. Bulk densities for all categories of mix proportions and production temperatures.

order of bitumen content from $5.75 \%$ to $4.50 \%$, by weight of binder gave a better compaction. The values are from $2.25 \mathrm{~g} / \mathrm{cm}^{3}$ at $0.25 \%$ Evotherm content and $5.75 \%$ bitumen content at $100^{\circ} \mathrm{C}$ production temperature to $2.35 \mathrm{~g} / \mathrm{cm}^{3}$. There is consistency in the compaction densities at higher content of Evotherm from 1\% to $1.25 \%$. Above these values, there is slight drop in the compaction, which could be as a result of high flow rate of the mixdue to excessive Evotherm content which reacted more with the bitumen. For the optimal mix the bulk densities or bulk specific gravity of compacted asphalt is $2.35 \mathrm{~g} / \mathrm{cm}^{3}$.

Excessive voids in the mixture would result in cracking due to insufficient binders to coat the aggregates, while too low air void may induce more plastic flow (rutting) and bleeding. For this reason, the Federal Ministry of Works and Housing (FMWH) Specification, specifies that the minimum void in the total mix of binder and aggregate should not be less than $3 \%$ and $5 \%$ maximum. Figure 11 shows the different voids in the total mix. From the results, at $100^{\circ} \mathrm{C}$ production temperature for admixed samples at $0.25 \%$ by weight of the total binder content shows a high void percentage. This is due to the fact that the asphalt material at $0.25 \%$ Evotherm content by weight of mix is exhibiting the property of HMA with higher voidsand lower density.

However, the voids in total mix of mixtures are located within the specification range of $3 \%$ to $5 \%$ for all mixes with production temperature of $115^{\circ} \mathrm{C}$ and above with minimum Evotherm content of $0.25 \%$ which supports the use of these Evotherm additives. For the optimal mix value, the void in total mix is $3.80 \%$.

In Figure 12, at control sample, voids filled with bitumen for $145^{\circ} \mathrm{C}$ and $160^{\circ} \mathrm{C}$ show similar percentage. This is unconnected to the high temperature of production, which enhances uniform mix of all constituent materials for the conventional production. At lower production temperature for the control sample, the void is lower, which indicates lower binder fill and subsequent increase in voids in total mix for the category of $100^{\circ} \mathrm{C}$ to $115^{\circ} \mathrm{C}$ production temperatures. 


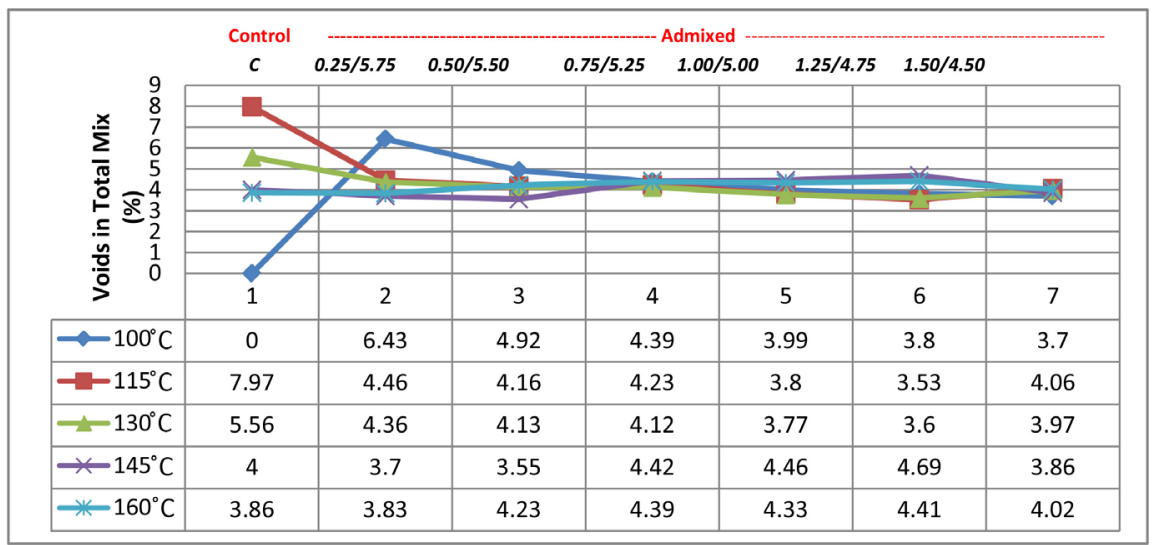

Figure 11. Voids in total mix for all categories of mix proportions and production temperatures.

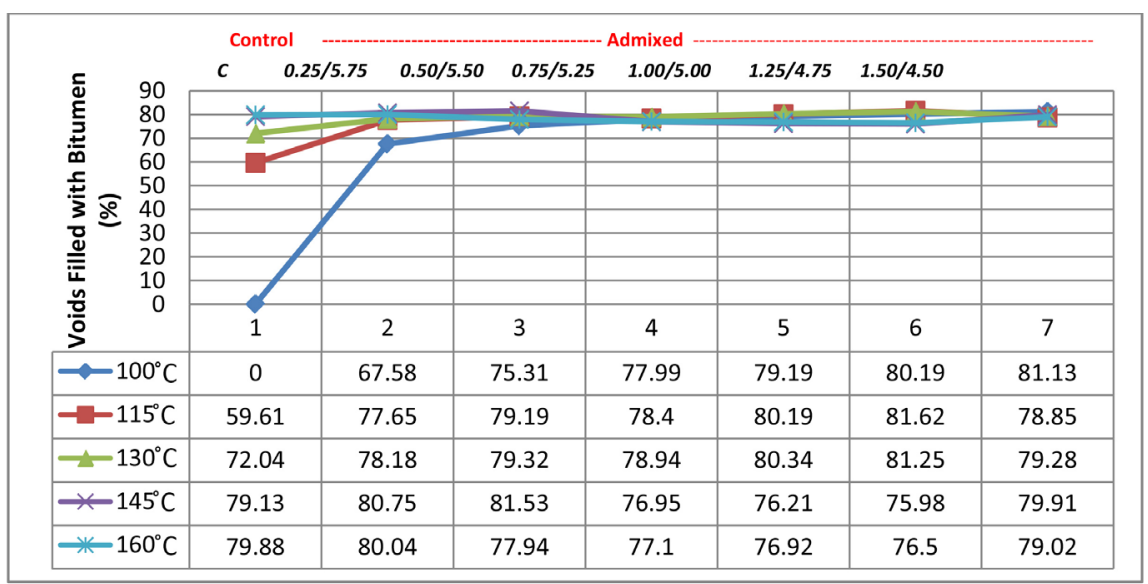

Figure 12. Voids filled with bitumen for all categories of mix proportions and production temperatures.

For the admix category of mixes, Voids Filled with Binder (VFB) is inversely related to voids in total mix in Figure 12 and hence as voids decreases, the VFB increases. The decrease of VFB indicates a decrease of effective bitumen film thickness between aggregates, which will result in higher low-temperature cracking and lower durability of bitumen mixture since bitumen perform the filling and healing effects to improve the flexibility of mixture.

The Nigerian specification states that the void filled with Bitumen or Binder should be between $75 \%$ to $82 \%$ for a wearing course asphalt design. Therefore, as mentioned above, samples at $0.25 \%-0.50 \%$ Evotherm content with lower production temperature of $100^{\circ} \mathrm{C}$ to $115^{\circ} \mathrm{C}$ which shows higher voids in total mix has lower voids filled with binder, whereas all other mixes are within specification band. For the optimal mix value, the void filled with binder is $80.19 \%$. It is closer to the upper limit band which indicates sufficient binder content.

From the graphical pattern in Figure 13, there is a gradual increase in the flow rate from the control sample to the admixed sample with maximum Evotherm content of $1.50 \%$ by weight of total binder. These pattern shows a shift from the 


\begin{tabular}{|c|c|c|c|c|c|c|c|c|}
\hline \multirow{6}{*}{$\begin{array}{l}\bar{\xi} \\
\underline{\xi} \\
\frac{3}{4} \\
\frac{0}{4}\end{array}$} & \multicolumn{2}{|r|}{ Control } & & . & Admixed & & \multirow[b]{2}{*}{$1.50 / 4.50$} & - \\
\hline & \multirow{5}{*}{$\begin{array}{l}5 \\
4 \\
3 \\
2 \\
1 \\
0\end{array}$} & $0.25 / 5$. & $\begin{array}{ll}5 & 0.50 / 5.50\end{array}$ & $0.75 / 5.25$ & $1.00 / 5.00$ & $1.25 / 4.75$ & & \\
\hline & & & & & & $\Longrightarrow$ & 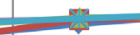 & $\Rightarrow$ \\
\hline & & it & $=$ & 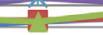 & $\Longrightarrow$ & & & \\
\hline & & 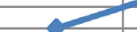 & & & & & & \\
\hline & & 1 & 2 & 3 & 4 & 5 & 6 & 7 \\
\hline & $00^{\circ} \mathrm{C}$ & 0 & 1.95 & 2.25 & 2.5 & 3.2 & 3.8 & 4.25 \\
\hline & $15^{\circ} \mathrm{C}$ & 1.95 & 2.35 & 2.3 & 2.5 & 3.1 & 4 & 4.05 \\
\hline & $30^{\circ} \mathrm{C}$ & 2.05 & 2.5 & 2.25 & 2.9 & 3.7 & 4.1 & 4.15 \\
\hline & $45^{\circ} \mathrm{C}$ & 2.5 & 2.65 & 3.35 & 3 & 3.9 & 4 & 4.3 \\
\hline & $60^{\circ} \mathrm{C}$ & 2.85 & 3.3 & 3.4 & 3.4 & 3.8 & 4.05 & 4.3 \\
\hline
\end{tabular}

Figure 13. Marshall flow for all categories of mix proportions and production temperatures.

low flow rate to the required flow rate, which is within the specification to excessive flow rate. Therefore, there is a 3-phase flow pattern in the representation; Low flow, Moderate flow and High low. The moderate flow is within the specification of $2 \mathrm{~mm}$ to $4 \mathrm{~mm}$.

Flow values of Evotherm mixtures increases as shown in Figure 13 owing to the reaction of bitumen and Evotherm viscosity property of the mixture, the mixes become more flexible and the resistance to deformation decreases resulting in a high flow value at higher Evotherm content. However, flow values at $115^{\circ} \mathrm{C}$ and above $115^{\circ} \mathrm{C}$ are within the required specification range of 2 to $4 \mathrm{~mm}$ except for the control sample. But above 1.25\% Evotherm content by weight of binder and $4.75 \%$ bitumen content by weight of binder at a production temperature of $130^{\circ} \mathrm{C}$ and above, the flow is outside the specification band at the upper limit (i.e. excess flow). Similarly, at 1.50\% Evotherm content by weight of binder and $4.50 \%$ bitumen content by weight of binder at all production temperatures of between $100^{\circ} \mathrm{C}$ to $160^{\circ} \mathrm{C}$, the flow rate are all above $4 \mathrm{~mm}$ which is the maximum recommended by the specification. This is due to the high Evotherm content which induces reaction by increasing the deformation. For the optimal mix value, the Marshall flow $3.1 \mathrm{~mm}$. It is approximately the mean value of the specification range of $2-4 \mathrm{~mm}$.

It is evident that the presence of Evotherm in the mixtures effectively improves the stability values at the appropriate mix ratios and proportions. Figure 14 shows the behavior of the stabilities which results in an improvement of mixture toughness. Stability values were low for the control sample at low temperature but increased significantly with increased Evotherm content even at lower temperatures to a maximum value of $9.7 \mathrm{KN}$ and later decreases with increasing Evotherm content. This is due to the high deformation because of high reaction of bitumen/Evotherm material that affects the viscosity property.

It may be noted that all admixed samples above $1 \%$ Evotherm content by weigh of binder and 5\% bitumen content at lower temperature gave stability values above the minimum of $3.5 \mathrm{KN}$ required by the specification. 


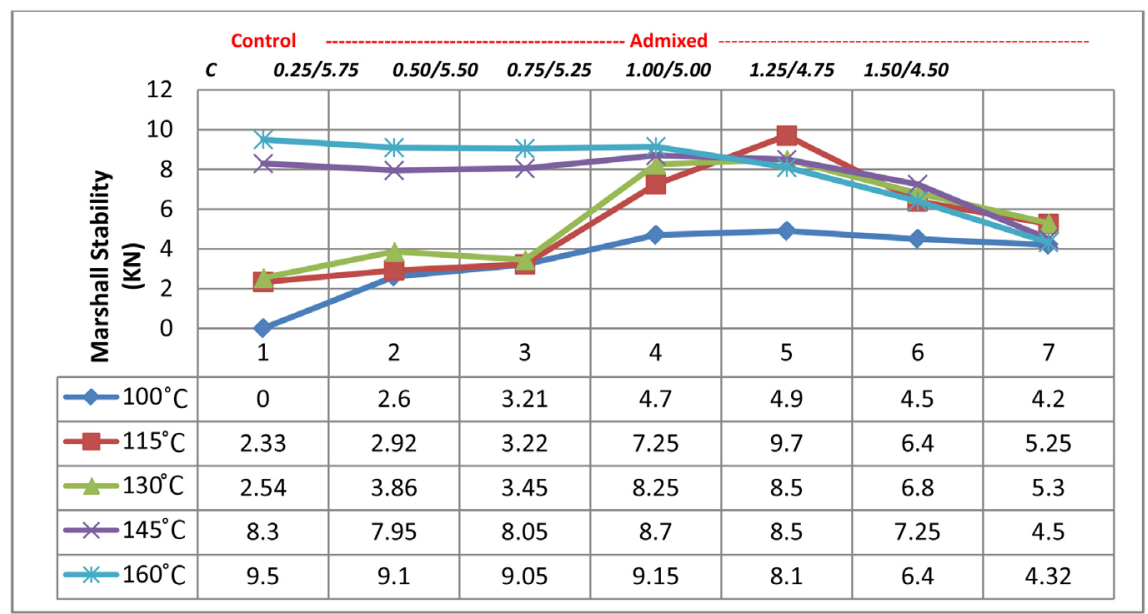

Figure 14. Marshall stability for all categories of mix proportions and production temperatures.

\section{Conclusion}

At the optimal mix point, the Bulk Specific Gravity is $2.35 \mathrm{~g} / \mathrm{cm}^{3}$; the Voids in Total Mix is 3.80\%; Voids in Mineral Aggregates is $19.20 \%$; Voids Filled with Bitumen is $80.19 \%$; the Marshall Flow is $3.1 \mathrm{~mm}$ and the Marshall Stability is 9.7 $\mathrm{KN}$. The admixed asphalt exhibited similar engineering properties as HMA even at low temperature of $115^{\circ} \mathrm{C}$. Lastly, the use of Evotherm in the asphalt mix production reduced the temperature from $163^{\circ} \mathrm{C}$ to $115^{\circ} \mathrm{C}$. This represents $29.5 \%$ temperature reduction.

\section{Recommendations}

1) Evotherm could be use in partial replacement in bitumen for Warm Mix Asphalt (WMA) production in Nigeria.

2) Several trials could be made in order to build confidence in the use of Evotherm in Warm Mix Asphalt (WMA).

3) Since global warming is now a reality, Warm Mix Asphalt (WMA) should gradually replace Hot Mix Asphalt (HMA) to reduce carbon footprint from asphalt pavements.

The introduction of cool pavement could be used to further reduce pavement albedo on Nigerian roads.

\section{Conflicts of Interest}

The authors declare no conflicts of interest regarding the publication of this paper.

\section{References}

[1] Dorchies, H. and Neitzke, B. (2005) "Green Engineering" European Practice. FHWA. Report No. FHWA-PL-08-007, 111-123.

[2] Hurley, G.C. and Prowell, B.D. (2006) Evaluation of Evotherm for Use in Warm-Mix 
Asphalt. Report No. NCAT Report 06-02, National Center for Asphalt Technology, Auburn.

[3] Hurley, G.C., Prowell, B.D. and Kvasnak, A. (2008) Ohio Field Trial of Warm Mix Asphalt Technologies: Construction Summary. Draft Report, National Center for Asphalt Technology, Auburn.

[4] Zettler, R. (2006) Warm Mix Stands up to Its Trial. February 2006, Better Roads Magazine.

[5] ELS Group (2004) Asphalt Emission Study: Shelly and Sands Conventional Mix and Warm Mix Asphalt Paving State Route 541 Coshocton and Guernsey Counties, Ohio August to September 2004. Report for Project No. 2004-103-R, ELS Group, Dublin.

[6] Romier, M., Koenders, B.G., Stoker, D.A., Robertus, C., Larsen, O. and Johansen, J. (2004) WAM-Foam, Asphalt Production at Lower Operating Temperatures. Proceedings, 9 th Conference of International Society for Asphalt Pavements, Copenhagen, 2002, 17-19.

[7] Csanyi, L.H. (1956) United Nations Conference on the Environment and Sustainable Development. Rio De Janeiro.

[8] Chevron (1977) Butumuls Mix Manual. Chevron USA, Asphalt Division, California.

[9] U.S. Environmental Protection Agency (2008) Clean Air Interstate Rule: Iowa. https://www.epa.gov

[10] Button, J.W., Estakhri, C. and Wimsatt, A. (2007) A Syn-Report of Warm-Mix Asphalt. Report No. SWUTC/07/0-5597-1. Texas Transportation Institute, The Texas $A$ and M University System, College Station.

[11] Jenkins, K.J., de Groot, J.L.A., van de Ven, M.F.C. and Molenaar, A.A.A. (1999) Half-Warm Foamed Bitumen Treatment, a New Process. 7 th Conference on Asphalt Pavements for Southern Africa, Victoria Falls, 1999, 27-32.

[12] Eyo, T.B. (2013) Cold Asphalt for the Federal Roads Maintenance Agency, (FERMA), Abuja, Nigeria. Patented Work.

[13] National Center for Asphalt Technology (NCAT) (2005) Researchers Explore Multiple Uses of Rejuvenators. Vol. 26, No. 1, Spring Issue.

[14] Cervarich, K., Abraham, J., Butz, T., Hildebrand, G. and Riebeseh, L. (2003) Asphalt Flow Improvers as Intelligent Fillers for Hot Asphalts-A New Chapter in Asphalt Technology. Sasol Wax GmbH, Hamburg.

[15] Alhassan, H.M. and Suleiman Arafat, Y. (2015) Evaluation of Nigerian Based Bitumen Modified with Additives. International Conference on Safe, Efficient and Sustainable Road Transportation in Nigeria, Abuja, 23-25 June 2015, 3-5.

[16] Easa, S. (2017) The Design Method of Asphalt Mixtures Considering Uncertainty. Journal of Testing and Evaluation, 47, 402-423.

[17] Federal Ministry of Works \& Housing (1997) Specification for Roads and Bridges Vol. II. FMW\&H, Ministry of Works, Abuja.

[18] Susan, T., Micheal, E. and Eyo, T.B. (2011) Road Maintenance Best Practices Guide. Federal Roads Maintenance Agency, Abuja, 133-142.

[19] Buttlar, W. and Roque, R. (1994) Development and Evaluation of the SHRP Measurement and Analysis System for Indirect Tensile Testing at Low Temperatures. Transportation Research Board Meeting.

[20] Westvaco, M. (2012) Evotherm and Warm Mix Asphalt Production Information. http://www.ingevity.com 
[21] Buss, A. and Gordon, D. (2011) Fundamental Binder and Practical Mixture Evaluation of Polymer Modified Bituminous Materials. International Journal of Pavement Engineering, 5, 137-151. https://doi.org/10.1080/10298430412331314146 